\title{
Emendations to tissue typology in discomycetes
}

\author{
Jan Hengstmengel ${ }^{1,2}$ (it)
}

Received: 15 November 2019 / Revised: 9 March 2020 / Accepted: 16 March 2020

(C) The Author(s) 2020

\begin{abstract}
The term "textura oblita", referring to a tissue type in ascomycetes with apothecial ascomata, has caused much confusion to ascomycologists. Originally it was defined as a long-celled tissue type consisting of thick-walled hyphae with intercellular substance. However, this definition appeared not well, or not at all, applicable to the originally given examples like Phialea starbaeckii. This has resulted in two other definitions which are more or less the opposite of each other, viz. as a thick-walled tissue with gelatinized walls and as a thin-walled tissue embedded in a gelatinous matrix. The main issue is the location of the gelatinous substance in the relevant tissue: in the cell wall, extracellular, or both. Unfortunately all of the three tissues are called "gelatinous tissue", although the term "gelatinous tissue" according to its definition concerns only tissue with extrahyphal gel. This implies that essential information about the location of the gel is ignored. In effect, all three conceptions of textura oblita are reducible to versions of textura porrecta that differ in the location of the gel. Similarly other tissue types can occur in different versions.

The author discusses the postulated mechanisms of gel formation in fungal tissues. These concern disintegration of the outer layer(s) of hyphal walls, disintegration of hyphae, and secretion, here linked to exocytosis. There is supposed to be a correlation between the way of gel formation on the one hand, and the structure of the sporocarp and the cell wall in ascomycetes and basidiomycetes on the other hand.

To conclude, an emended tissue typology is provided in which the distinguished versions of the six basic tissue types are arranged according to the shape of their cells, the arrangement of their hyphae, the occurrence of thickened cell walls, and the occurrence of extracellular gel.
\end{abstract}

The species name Cyathicula starbaeckii, comb. nov., is validly published here.

Keywords Ascomycetes · Tissue types · Thickened cell walls · Gelatinous matrix $\cdot$ Textura oblita $\cdot$ Cyathicula starbaeckii

\section{Introduction}

Henderson (1972) described the excipulum of the moss inhabiting discomycete "Helotium" dicrani Ade \& Höhn. as having hyphal walls which "are sufficiently slightly thicker and glassy to merit the term "textura oblita"”. However, when examining four of his collections of this

Section Editor: Roland Kirschner

Jan Hengstmengel

j.hengstmengel@umail.leidenuniv.nl

1 Section Botany, Naturalis Biodiversity Center, P.O. Box 9517, 2300 RA Leiden, The Netherlands

2 Hortus Botanicus, Leiden University, P.O. Box 9500, 2300 RA Leiden, The Netherlands species, I realized that the outer excipulum was composed of slightly winding, long-celled and apparently thin-walled, hyaline hyphae immersed in a gel and not of thick-walled hyphae, so this tissue might be considered a gelatinized textura porrecta (Hengstmengel in prep.). For clearness' sake, it has to be pointed out that $H$. dicrani sensu Henderson is not identical with $H$. dicrani in the sense of Spooner (1984). The ectal excipulum of the latter contains isodiametric, angular or subglobose, thin-walled cells (textura angularis to globulosa) and for that reason Spooner placed it, together with some similar bryicolous discomycetes, in the newly erected genus Bryoscyphus Spooner.

Motivated by the discrepancy between Henderson's description and my own observations of the outer excipulum of $H$. dicrani sensu Henderson, in particular with regard to the terms "textura oblita" versus "gelatinized textura porrecta", I reviewed the literature (in print and online) to 
explore how the term "textura oblita" has been defined and how it has been and still is used by different authors. The results of this study are given below.

\section{Results and discussion}

\section{Textura oblita}

The expression "verklebtes Filzgewebe" (literally "agglutinated felt tissue") or in Latin "textura oblita" (from oblitus, past participle of oblinere $=$ to smear) was introduced by Starbäck (1895). He used the term "Filzgewebe" with the meaning "Geflechte deutlicher Hyphen" (wicker work of distinct hyphae) following de Bary (1884). Starbäck defined textura oblita as a tissue composed of long-celled, more or less parallel running hyphae with narrow lumina and strongly thickened walls which grow or are glued together. As a consequence, he stated, an "intercellular substance" is formed, which may be very extensive. He mentioned Phialea - with species like $P h$. "Starbäckiil, Ph. bicolor, and Ph. caulicola - as a genus in which textura oblita is the dominating tissue in the lateral and basal parts of the excipulum as well as in the stalk of the apothecium. As Phialea starbaeckii, Ph. bicolor, and Ph. caulicola are well-known species, nowadays classified in Crocicreas or Cyathicula, it is obvious which tissue Starbäck meant (see Fig. 6). His interpretation of this tissue, however, is unclear and raises some questions. If the hyphal walls have glued or even grown together, there is no interstitial space left wherein an intercellular substance can be formed. In the figure on p. 11 and in Tafel II, Fig. 24 g, however, there appears to be enough interstitial space within the "verklebtes Filzgewebe" where an intercellular substance could be located but the hyphal walls do not look glued or grown together (see Figs. 1 and 2). Did Starbäck suppose that this substance is formed within and excreted from the thickened hyphal walls? Unfortunately he did not clarify this, neither the origin and consistency of the substance.

Korf $(1951,1958)$ slightly adapted Starbäck's tissue type terminology, mainly by using the term "textura globulosa" in a narrower sense and adding the term "textura angularis". He redefined "textura oblita" as long-celled tissue consisting of hyphae "running in one direction, more or less parallel" and "with narrow lumina and strongly thickened walls, cohering", so hardly different from Starbäck. Korf, however, illustrated it rather differently, namely with tightly packed hyphae and hardly any interstitial space (Korf 1958; reproduced here in Fig. 3). According to his extensive "Key to families, subfamilies, tribes and important genera of Helotiales", he adopted the opinion that this tissue type occurs inamong others - the genus Cyathicula, at least before full development of the excipulum (Korf 1973, see especially key options 167 and $168^{\prime}$ on p. 306). Likewise, some years earlier, Dennis (1956b) described the excipular hyphae in Phialea as having walls "greatly thickened, often as thick as the lumen, very glassy", be it without use of the term "textura oblita". But did Korf and Dennis really observe lateral cell boundaries, i.e., the outermost mannoprotein layer of the cell walls, somewhere in the middle of the glassy substance between two mutually adjacent lumina of the outer excipulum? Although they mention thickened cell walls explicitly, they never mark cell boundaries in their illustrations of particular species, except in schematic representations of tissue types (Korf 1958, 1973). In any case, they do not mention any "intercellular substance", as Starbäck did. According to Dennis, the excipular hyphae usually terminate in protruding thin-walled cells which in some species excrete tabular crystals, especially in the marginal zone of the receptacle. With this statement, he suggests that the thickness of the cell walls more or less abruptly decreases at the margin of the excipulum.

These protruding thin-walled cells provided with crystals are clearly shown by Carpenter (1981) in many drawings in his monograph of Crocicreas. In this publication, the genus Crocicreas is conceived in a very broad sense, including the genus Cyathicula and many species of the former genus Phialea, among others, Ph. starbaeckii, ${ }^{1} \mathrm{Ph}$. bicolor, and $\mathrm{Ph}$. caulicola (the latter tentatively synonymized with Crocicreas cyathoideum var. cacaliae). In Carpenter's monograph, however, several drawings of longitudinal sections through the flanks and margins of apothecia are demonstrating that the excipular cells are not thick-walled at all. In reality, the protruding thin-walled marginal cells are the endings of similarly thin-walled, ectal excipular hyphae which are embedded in a gel and therefore they are relatively widely spaced (see Fig. 4). So, his interpretation of the ectal excipular tissue is totally different from the ones of Starbäck and Korf, both of whom postulated that the hyphae are thick-walled. Given that Starbäck had called the relevant tissue type of Crocicreas "textura oblita", Carpenter changed its definition into "long-celled, narrow, thin-walled hyphae immersed in a gel", so that he could keep saying that the presence of this tissue type in the ectal excipulum is a unifying feature of the genus Crocicreas (Carpenter 1981). This essential modification of the definition has escaped the attention of most authors. As a matter of fact, Dennis (1956b) already observed these "slender

\footnotetext{
${ }^{1} \equiv$ Cyathicula starbaeckii (Rehm) Hengstm., comb. nov. MycoBank No. 831119. Basionym: Phialea starbaeckii Rehm (as "Starbäckii”) in Starbäck, Bih K svenska Vetensk-Akad Handl 21, afd 3, no 5: 33 (1895). The combination Cyathicula starbaeckii (Rehm) S.E. Carp. (Index Fungorum No. 587192) was not validly published by Tholl et al. (2000) because of being not in accordance with the International Code of Nomenclature for algae, fungi, and plants, art. 41.5 (basionym and reference missing). Actually this combination was erroneously ascribed by them to Carpenter, who only transferred Ph. starbaeckii to the genus Crocicreas Fr. (Carpenter 1980).
} 


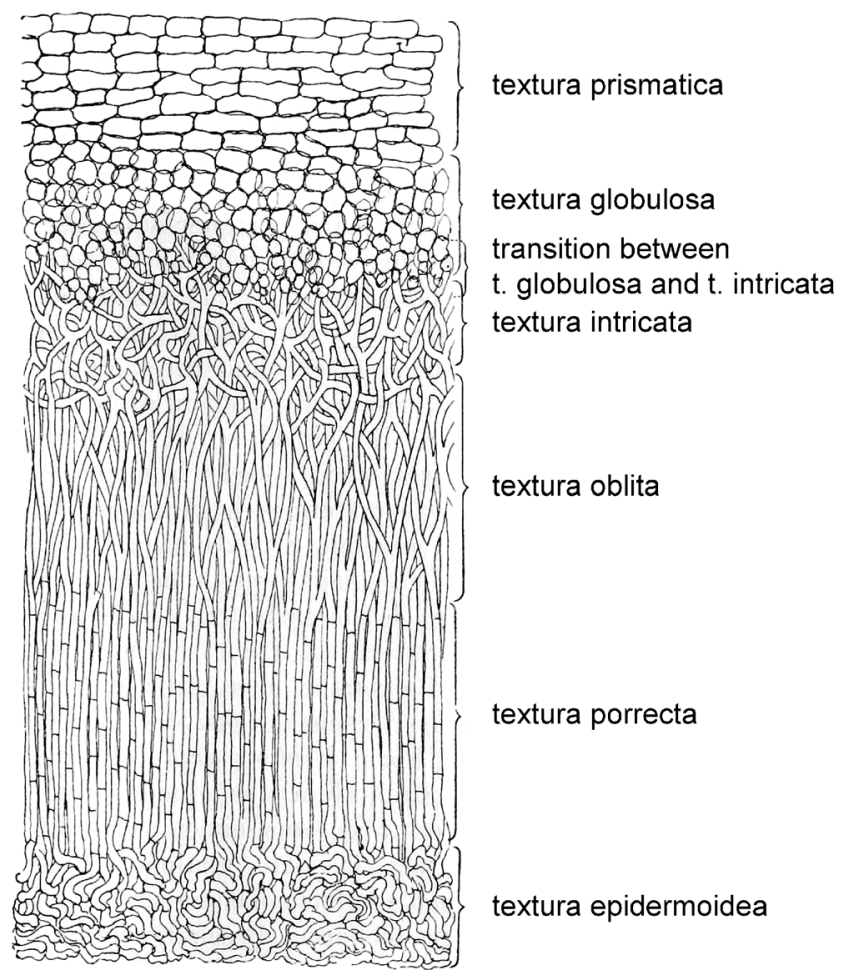

Fig. 1 Schematic presentation of some textura types of discomycetes (reproduced from Starbäck 1895)

hyphae in a hyaline gelatinized matrix" in Cyathicula coronata.

Johnston et al. (2014) appear to use the term "textura oblita" simultaneously for two different tissue types, particularly in the central layer of the ectal excipulum in Torrendiella setulata: a strongly gelatinized, \pm vertically oriented tissue at the flanks, and a tissue of narrow, long-cylindrical cells immersed in abundant gel and oriented at a low angle to the surface towards the margin. So it looks like some authors consider textura oblita to be synonymous with gelatinized tissue.

Strictly speaking, the term "textura oblita" as defined by Starbäck is not applicable to the excipulum of species of Phialea (or partly synonymous genera) or species like Crumenula (Godronia) linnaeae for which two taxa it originally was conceived, because of misinterpretation: Starbäck postulated thick-walled hyphae with "intercellular substance" whereas this combination of features is not present in the taxa concerned. If Starbäck would have meant that the thick cell walls disintegrate to form gel (see "Gel formation" section), the (gelatinous) substance would not be intercellular but

\footnotetext{
${ }^{0} \equiv$ Cyathicula starbaeckii (Rehm) Hengstm., comb. nov. MycoBank No. 831119. Basionym: Phialea starbaeckii Rehm (as "Starbäckii") in Starbäck, Bih K svenska Vetensk-Akad Handl 21, afd 3, no 5: 33 (1895). The combination Cyathicula starbaeckii (Rehm) S.E. Carp. (Index Fungorum No. 587192) was not validly published by Tholl et al. (2000) because of being not in accordance with the International Code of Nomenclature for algae, fungi, and plants, art. 41.5 (basionym and reference missing). Actually this combination was erroneously ascribed by them to Carpenter, who only transferred Ph. starbaeckii to the genus Crocicreas Fr. (Carpenter 1980).
}

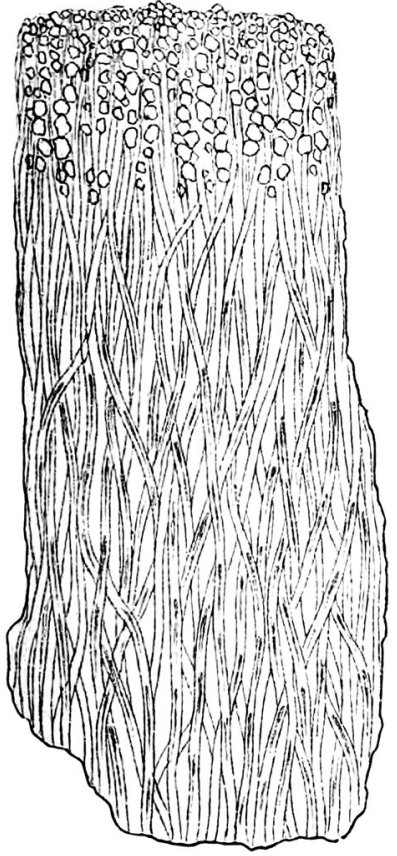

Fig. 2 Surface view of the outer excipulum of Cyathicula starbaeckii showing textura oblita sensu Starbäck and at the margin calcium oxalate crystals (reproduced from Starbäck 1895)

"interluminar". The same final conclusion applies to textura oblita as defined by Korf. Carpenter's meticulous observation that the outer excipular hyphae in these genera are thin-walled and immersed in a gel gave rise to a third definition of "textura oblita". This makes the use of the term "textura oblita" very confusing. Of course one could indicate which conception is followed but that is usually not done. As nobody appears to follow Carpenter's definition, probably all other authors use "textura oblita" in the sense of Korf $(1951,1958,1973)$, as is also done in Dictionary of the Fungi (Kirk et al. 2008). Although textura oblita in this sense does not occur in Cyathicula or synonymous genera, several recent authors still assert that the outer excipular hyphae in these genera are

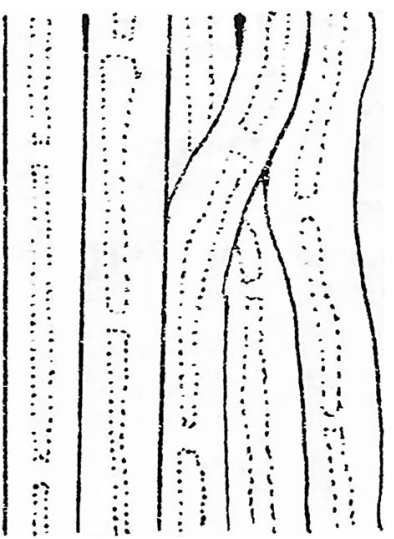

Fig. 3 Textura oblita sensu Korf (reproduced from Korf 1958, with permission of the copyright holders). Remarkably the boundaries between two adjacent cells in the same hypha are not shown, which cannot be realistic 


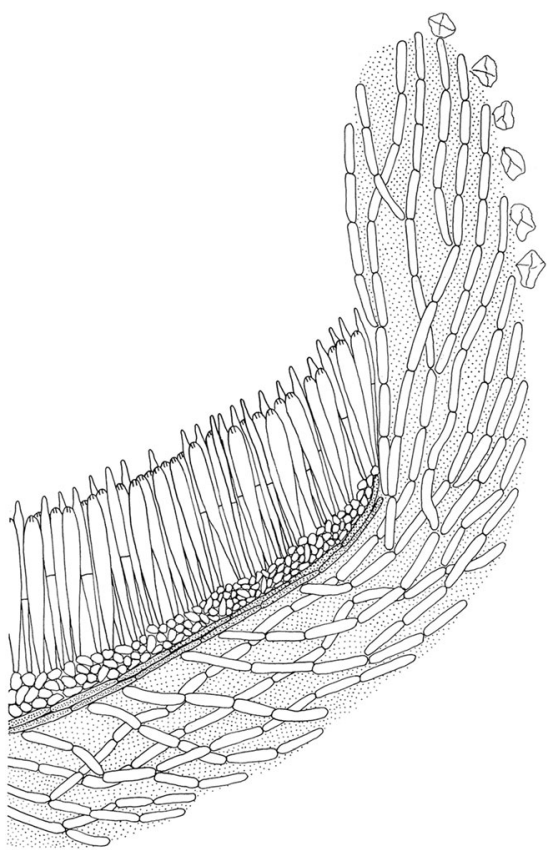

Fig. 4 Longitudinal section through the upper flank and margin of an apothecium of Cyathicula starbaeckii. The outer excipulum consists of textura oblita sensu Carpenter. Illustration by Susan Joyal (reproduced from Carpenter 1981, with permission of the publisher. (C) 1981, The New York Botanical Garden Press, Bronx, New York)

forming a textura oblita, so a tissue with thick-walled hyphae. See, e.g., Iturriaga et al. (1999), Vermeulen (1999), Rubio Domínguez (2013), Quijada et al. (2017), and Wagner (2019).

It is evident that the term "textura oblita" as defined by Starbäck and Korf will always be associated with the taxa to which it was applied by Starbäck, and so the confusion will continue. Therefore, it is better to avoid this confusing and frequently misapplied term. Luckily there are good substitutes for it, depending on which of the three definitions (Starbäck, Korf, Carpenter) is meant. Before disclosing these, as parts of an emended tissue typology, it is useful to touch more deeply on gelatinous tissue and the ways in which it is formed.

\section{Gel(atinous) tissue}

Fungal tissue in which the hyphae of whatever shape or direction are embedded in a gelatinous matrix is called "gelatinous tissue" or "gel tissue" (Moore 1965a, 1965b, 1965c; Dixon 1974a; Kirk et al. 2008). Moore (1965c) made a distinction between an "incomplete" and a "complete gel matrix". In the former, the gel is laid down only in the interstices of widely spaced hyphae; in the latter, the gel has expanded to occupy all space between hyphae and caused the hyphae to be displaced. According to the given definition, the term "gel(atinous) tissue" applies to tissues in which the gel is extracellular. This means that the embedded hyphae or cells themselves need not be gelatinized. However, "gelatinized hyphae" with thick and glassy walls exist as well, and these hyphae are not necessarily embedded in a gelatinous matrix. Such tissues with gelatinized hyphae do not fall under the aforesaid definition of gelatinous tissue as long as their hyphae are not embedded in a gelatinous matrix. Kirk et al. (2008) describe "gel tissue" as just "a mixture of gel and hyphae", but this ignores the fact that a tissue usually has a distinct structure.

Nannfeldt (1932) and Dennis (1956b) used the occurrence of a gelatinous matrix and cartilaginous thickened cell walls as additional characters to distinguish subfamilies in the Helotiaceae. They recognized nine subfamilies, among others, the Ombrophiloideae distinguished by an inner excipulum with slender, thin-walled, loosely interwoven hyphae (textura intricata) embedded in a large amount of mucilaginous matter. Two other subfamilies, viz. the Helotioideae and Trichoscyphelloideae, were said to be provided with an outer excipulum of textura oblita with often thickened, cartilaginous-gelatinous cell walls. Another subfamily, the Phialeoideae, is-according to Nannfeldt — characterized by an excipulum with rather thin, parallel hyphae which possess neither gelatinous nor cartilaginous walls and "as seen from outside" form a typical textura oblita. According to this somewhat enigmatic circumscription, the hyphae are rather thin but should look like having thickened but not glassy walls. Dennis modified this circumscription to "rather slender parallel hyphae with thickened walls and thin septa", without indicating whether the thickened walls are gelatinized, cartilaginous, or not translucent at all. Although the subdivision of the Helotiaceae as used by Nannfeldt and Dennis has become outdated as a result of more recent morphological-anatomical and molecular research, the presence or absence of gelatinous material among hyphae is still a valuable discriminative character.

Unfortunately the terms "gelatinous tissue" and "(non-gelatinous tissue with) gelatinized hyphae" are very often not properly distinguished from each other. In his generic description of Cyathicula, Dennis (1956b) speaks of "Excipulum of strongly gelatinized hyphae". This is in accordance with his specific description of $C$. dolosella ("Hyphae with thickened, gelatinized walls"), but conflicting with the specific description of the congeneric C. coronata (hyphae "slender, $2 \mu \mathrm{m}$ thick, lying in a hyaline gelatinized matrix"). Korf (1951) distinguished the Arachnopezizeae from other tribes of the Hyaloscyphaceae by the property that the ectal excipulum consists of rather thick-walled gelatinized textura prismatica to textura angularis (p. 139). From several species descriptions and the adjective "rather thick-walled", it appears that not the relevant tissue is gelatinized but only the hyphal walls. Something similar applies to Korf (1958) where the type species and allies of Chlorociboria are said to have the ectal excipulum consisting of "textura intricata, usually with distinctly gelatinized walls" (p. 21). In the determination key on p. 23, this is formulated as "ectal excipulum of gelatinized textura intricata". Korf 
(1973) at first made a clear distinction between "hyphae with gelatinized walls" and "hyphae in a gel" (p. 251; p. 283, key option 7'), but further on used these terms promiscuously as if they are synonymous; see, e.g., p. 298, option 116 ("gelatinized hyphae") and dichotomy 121-121' ("gel layer"); p. 300, option 134 ("gelatinized hyphae" versus "nongelatinized tissue") and option 134' ("gelatinized hyphae" and "tissue gelatinous or not"); p. 301, option 138 ("hyphae immersed in a gel" versus "nongelatinized cells"). Dixon (1974a, 1974b) used to distinguish carefully "gelatinized hyphae" from "gel tissue", but unfortunately rephrased "hyphae gelatinized but not embedded in a gel" in Chloroscypha and Chlorociboria (Dixon 1974a: key option 12') in the generic description of Chlorociboria as "gelatinized textura" (Dixon 1974b). This is extremely confusing, because "gelatinized textura" in this sense is definitely not identical with "gel(atinous) tissue", although "textura" actually means "tissue". Johnston and Park (2005) are using the expressions "gelatinous" and "non-gelatinous" ectal excipulum or textura mostly in the sense that the cell walls concerned are "thickened and gelatinous" or not (see p. 682), but on p. 699, they confusingly state that the ectal excipulum of Chlorociboria colubrosa is "gelatinous", be it with the explanation "embedded in hyaline gelatinous matrix" in parentheses.

In general, it is regrettable that by considering the expressions "hyphae in a gel" and "hyphae with gelatinized walls" synonymous and interchangeable, two different and taxonomically important features are lumped. It is true that both tissue with gelatinized hyphal walls and tissue with hyphae surrounded by gel use to have a refractive, glassy appearance, but careful observation in order to make a distinction between the differently defined tissue types would be advisable.

\section{Gel formation}

Moore (1965a, 1965b, 1965c) investigated with light microscopy the ontogeny of gelatinous fungi and gel tissues in some Helotiales and in one representative of the "Tremellales". Before 1965, authors presumed that gels in fungi arise from disintegration or gelatinization of hyphal walls. Moore (1965c), however, found that gel in sporocarps may arise in two fundamentally different ways.

The first way is by disintegration of hyphae. This was demonstrated in the basidiocarp of Pseudohydnum gelatinosum (Exidiaceae) and in the conidiophores of "Coryne" (Ascocoryne) cylichnium (Helotiaceae). In the former, the hyphae of a previously non-gelatinous tissue gradually degrade causing the relevant tissue to become gelatinous. In the latter, the hyphal walls swell markedly and then gelatinize or disintegrate at localized sites, resulting in disintegration of the conidiophores. Hyphal disintegration to form gel was not observed in excipular tissues of discomycetes. Moore studied only one representative of the jelly fungi, currently known as a rather heterogeneous, paraphyletic group of basidiomycetes (Hibbett 2007). Therefore, Moore's results do not exclude that gel also may be formed by disintegration of merely (part of) the walls of hyphae. Nowadays, Pseudohydnum is classified in the family Exidiaceae (Auriculariales) and considered not closely related with, e.g., Tremella species (Tremellaceae, Tremellales). Electron microscopic investigations have clearly shown that the walls of basidiomycetous yeasts, e.g., the haplonts of Tremella species and the pucciniomycete Leucosporidium gelidum (see micrograph at www.mycobank.org), consist of multiple layers. When these yeasts are budding, the outer wall layers are ruptured and disintegrate, presumably after new wall material has been deposited at the inside of the parent wall (Bandoni and Bisalputra 1971; Srivastava and Smith 1974; Moore 1978; van der Klei et al. 2011). Similarly, disintegration of outer wall layers might be involved in the production of extracellular gel, just as it might be in the formation of the polysaccharide capsule of Tremella haplonts (Bandoni and Bisalputra 1971). If gel arises by disintegration of (part of) the walls, it is plausible that the gel is composed of the same or similar chemical constituents as the cell walls. About Tremella mesenterica and some other basidiomycetes, it is known that the mucilage principally consists of uronic acids (Moore 1965c) , but the presence of uronic acids in fungal walls has almost exclusively been found in ascomycetes and Mucor (BartnickiGarcia 1968). It is, however, conceivable that the mucilage of uranic acids also may be formed by chemical modification of decomposition products of the wall. Anyhow, at present the knowledge about disintegration of hyphal walls to form gel is still far from complete and lacking molecular and electron microscopic evidence. It is noteworthy that Korf (1973) applied this way of gel formation to apothecia. I doubt whether this is justified, because the structure of cell walls in ascomycetes is different from the one in basidiomycetes. Ascomycetous cell walls are bilayered and consist of only one electron-transparent inner layer (mostly containing chitin and $\beta$-glucans), and one outer layer of long, protruding fibrils (mostly composed of mannoproteins) which can collapse to a thin electron-dense layer due to fixatives (Kreger-van Rij and Veenhuis 1971; Kirk et al. 2008; van der Klei et al. 2011; Gow et al. 2017). Hence, it is not very likely that disintegration of hyphal walls to form gel can occur in ascomycetes without damaging or degrading the hyphae concerned. After disintegration of the walls, the protoplasts would miss their protective and firmness giving covering and the tissue concerned would probably be shapeless and irreversibly dysfunctional, but that does not apply to ascomycetes with a gelatinous matrix. Degradation of cells does occur in conidiophores of "Coryne" cylichnium, but that appears to be a component of spore dispersal, just as, e.g., the liquefaction of the gills in inky caps (Coprinus and allied genera). Disintegration of cells appears also functional in many pyrenomycetes, including pyrenocarpous lichens like 
Pyrenula. During the development and riping of the asci, a hymenial gel arises in their perithecia, which probably happens by disintegration of the sterile paraphysoids, as their number gradually decreases (Döbbeler 1978).

The second way in which gelatinization may take place - as presented by Moore (1965c) - is by direct secretion of mucilage, i.e., the viscous precursor of gel, from the cytoplasm of the hyphal cells. She found that, prior to the secretion, mucilaginous inclusions become visible in the cytoplasm of the cells concerned, in some tissues preceded by enlargement of the nuclei. Then tiny pores are formed in the cell walls through which the mucilage is extruded. After the secretion, the mucilage is converted into gel by water absorption, subsequent swelling, and change in viscosity. Mucilage secretion turned out to be the origin of the gel in the medullary and/or outer ectal tissue of all discomycetes studied by Moore, e.g., "Coryne" cylichnium and Neobulgaria pura (both Helotiaceae), Leotia "viscosa" (= lubrica) and "Sphagnicola" (Pezoloma) obstricta (both Leotiaceae). Recent microbiological research has provided more insight into these observations. What Moore observed, most likely, is gel secretion via exocytosis, a process by which cells release material to their extracellular environment (Rieger et al. 1991). Exocytosis is a common phenomenon in many groups of prokaryotes and eukaryotes, including ascomycetes and basidiomycetes (Yoneda and Doering 2006; Casadevall et al. 2009; Schultzhaus and Shaw 2015). The "mucilaginous inclusions" appear to be concentrations of gel containing secretory vesicles which are targeted from the Golgi apparatus towards the plasma membrane and which traverse the membrane by means of multivesicular bodies. These multivesicular bodies fuse with the membrane and release extracellular vesicles into the extracellular space, that is to say, in organisms with cell walls, between the plasma membrane and the cell wall (Brown et al. 2015). The idea that vesicles transport material to the extracellular space between the plasma membrane and cell wall is well established (Casadevall et al. 2009), but how do they get across the rigid cell wall? Rodrigues et al. (2007) demonstrated with electron microscopy the presence of transient extracellular vesicals within fungal cell walls, so there must exist one or more mechanisms for crossing the cell wall. Moore (1965c) observed "tiny pores" (channels?) in excipular cell walls of some ascomycetes, but the existence of these has not yet been confirmed with electron microscopy. The same applies to the minute pores that have been observed with light microscopy in excipular hyphae of Pyronema domesticum (Moore-Landecker 1981). However, the existence of protein channels or structural cables in cell walls is involved in one of the three potential non-exclusive mechanisms of transit across cell walls, as postulated by Brown et al. (2015). The other postulated mechanisms, already indicated by Rodrigues et al. (2007), imply a passage forced by turgor pressure and/or a loosening of the wall facilitated by cell wall-modifying enzymes. Extracellular vesicles are able to carry a wide range of cargo, including nucleic acids, proteins, and polysaccharides (Brown et al. 2015), so it is conceivable that also gel forming fungal polysaccharides, like pectins and other polyuronides (Ulrich 1943; Moore 1965c), may be part of the cargo. In addition, a gel matrix may also occur in the hymenial layer of ascocarps. Besides pyrenomycetes (see above) also many discomycetes are known to have extracellular gel in their hymenium, especially around the paraphyses, e.g., species of the genera Claussenomyces and Chloroscypha (Dennis 1956b; Carpenter 1981). In apothecia of Pyronema domesticum, MooreLandecker (1981) found droplets of mucilage on the surface of paraphyses. She was probably the first who determined that these droplets were formed by secretion. Also many apothecial ascolichens possess hymenial gel, probably arisen by secretion, and its reaction with iodine-potassium iodide is widely used for determining species. I suppose that gel secretion via exocytosis is the only way in which a gelatinous matrix in apothecia is formed, whereas in perithecia gel formation by disintegration of hyphae is more usual, and in basidiocarps both ways of gel formation may take place, including by disintegration of only the outer layer(s) of the cell wall (see Table 1).

The gelatinous matrix in the excipulum of many discomycetes may be regarded as a specialized form of a so-called extracellular matrix. An extracellular matrix, also referred to as slime, is a polymeric conglomeration generally composed of extracellular biopolymers in various structural forms (Vert et al. 2012). These polymers are produced intracellularly and secreted via exocytosis (Plopper 2007). The extracellular matrix is found in all domains and its composition and function vary strongly among the different lineages. Gel tissues in fungi are believed to serve as a water reservoir, e.g., to survive droughts (Malloch 2019), for rapid growth or for extension of the spore discharge period (Ingold 1959). If the gel is formed by secretion, this does not automatically imply that it is composed of the same or similar polysaccharides as the adjacent cell wall. In extracellular matrices of biofilms, the polysaccharides appear to be either distinct from the cell wall or further modified after release from the cell wall (Mitchell et al. 2016). This suggests that in the former case the constituents are produced intracellularly and released via exocytosis, and that in the latter case resident vesicles in the wall or partial disintegration of the wall play a role.

Dennis $(1956 \mathrm{a}, 1956 \mathrm{~b})$ found in the outer excipulum of some Ombrophila species, among others “O." obstricta, slender hyphae "permeating" or embedded in a gelatinous matrix, and transferred these species to the new genus Pseudodiscinella (= Pezoloma). Apart from his assumption that this matrix (at least in the type species $O$. violacea) was formed by gelatinization of the outer portion of the hyphal walls, the term "permeating" in the former publication is actually less well chosen: it signifies that the hyphae are passing through an existing matrix, but in reality they secrete mucilage around themselves and subsequently form gelatinous "surroundings". Because of the presence of a gelatinous matrix, Dennis (1956b) classified Pseudodiscinella in the subfamily 
Table 1 The postulated mechanisms of the formation of extracellular gel in fungi and the occurrence in different groups as reported since 1965 ( $L M$, light microscopy; TEM, transmission electron microscopy)

\begin{tabular}{|c|c|c|}
\hline Mechanism & Occurrence in ascomycetes & Occurrence in basidiomycetes \\
\hline $\begin{array}{l}\text { Disintegration of outer } \\
\text { layer(s) of walls }\end{array}$ & - & $\begin{array}{l}\text { Suggested for Tremella haplonts (Bandoni } \\
\text { and Bisalputra 1971) }\end{array}$ \\
\hline $\begin{array}{l}\text { Disintegration of } \\
\text { hyphae }\end{array}$ & $\begin{array}{l}\text { Observed with LM in conidiophores of "Coryne" (Ascocoryne) cylichnium } \\
\text { (Moore 1965c) } \\
\text { Likely in paraphysoids of pyrenomycetes (Döbbeler 1978) }\end{array}$ & $\begin{array}{l}\text { Observed with LM in Pseudohydnum } \\
\text { gelatinosum (Moore 1965c) }\end{array}$ \\
\hline \multicolumn{3}{|l|}{ Secretion via exocytosis: } \\
\hline $\begin{array}{l}\text { a. Forced by turgor } \\
\text { pressure }\end{array}$ & $\begin{array}{l}\text { Suggested for Saccharomyces cerevisiae (Rodrigues et al. 2007; Brown et al. } \\
\text { 2015) }\end{array}$ & - \\
\hline $\begin{array}{l}\text { b. Facilitated by } \\
\text { wall-modifying en- } \\
\text { zymes }\end{array}$ & Suggested for Histoplasma capsulatum (Albuquerque et al. 2008) & - \\
\hline $\begin{array}{l}\text { c. Through wall } \\
\text { channels }\end{array}$ & $\begin{array}{l}\text { Observed with LM in Bulgaria inquinans, "Coryne" (Ascocoryne) cylichnium, } \\
\text { Corynella sp., Cudonia lutea, Holwaya leptosperma, and Leotia "viscosa" (= } \\
\text { lubrica) (Moore 1965c) } \\
\text { Observed with LM in the excipulum of Pyronema domesticum (Moore-Landecker } \\
\text { 1981) } \\
\text { Assumed for Neobulgaria pura and sp., and "Sphagnicola" (Pezoloma) obstricta } \\
\text { (Moore 1965c) } \\
\text { Suggested for Aspergillus fumigatus (Rodrigues et al. 2007; Brown et al. 2015) }\end{array}$ & - \\
\hline \multirow[t]{3}{*}{ d. Unspecified } & $\begin{array}{l}\text { Observed with TEM in Candida albicans and parapsilosis, Histoplasma } \\
\text { capsulatum, Saccharomyces cerevisiae, and Sporothrix schenckii } \\
\text { (Albuquerque et al. 2008) }\end{array}$ & $\begin{array}{l}\text { Observed with TEM in Cryptococcus } \\
\text { neoformans (e.g., Rodrigues et al. 2007) }\end{array}$ \\
\hline & Observed in paraphyses of Pyronema domesticum (Moore-Landecker 1981) & $\begin{array}{l}\text { Suggested for Malassezia sympodialis } \\
\quad(\text { Gehrmann et al. 2011) }\end{array}$ \\
\hline & Suggested for Paracoccidioides brasiliensis (Vallejo et al. 2012) & \\
\hline
\end{tabular}

Ombrophiloideae of the Helotiaceae. Perhaps it would have been more consistent if Dennis (1956b) had classified Cyathicula coronata in the Ombrophiloideae as well. After all, he described - in disagreement with his description of the subfamily and genus concerned - its excipular hyphae as "slender, undulating, more or less parallel, lying at a high angle to the surface in a hyaline gelatinized matrix". This circumscription has been confirmed by Carpenter (1981), but it has been known for longer that the presence of a gel layer is not exclusive for the subfamily Ombrophiloideae sensu Nannfeldt and Dennis (see, e.g., the key to the genera in Carpenter 1981).

In Korf's key, the genera Cyathicula s.l. and Calycella are keyed out by the feature that the hyphae or cells of the outermost layer of their excipulum have thickened, glassy walls which at fullest development become a refractive gel in which the hyphal lumina are embedded (Korf 1973: key option 167). This would mean that the gelatinous matrix in these two genera has arisen by breakdown of the hyphal walls. However, Carpenter (1981) in his extensive study of Crocicreas s.l. observed the cortical hyphae of this genus as thin-walled hyphae in a gelatinous matrix, which means that the gel must have been produced by secretion and not by disintegration of the walls, because the hyphal walls remained (visibly) unchanged. Therefore, it is not probable that the "gelatinized tissue, appearing to have widely spaced, parallel, thin walled hyphae immersed in a gel", like illustrated by Korf (1973: fig. 3 sub $\mathrm{H} 2$ ), has arisen by gelatinization (disintegration) of the thick walls of an earlier textura oblita, as Korf supposes.

\section{Gelatinous and incrassate derivations of basic tissue types}

In the tissue type terminology of Starbäck, no specific gelatinized tissues were distinguished. Starbäck (1895) merely mentioned that the gelatinous tissue of certain Bulgariaceae belongs to the long-celled tissues. Korf $(1951,1958)$ did not distinguish separate gelatinous tissue types either. In the latter publication, it is said at most that species of Ombrophila and Spagnicola in some layers possess thin-walled hyphae "in a gelatinous matrix" or "in a gel". Afterwards, Korf (1973) added to the conventional seven textura types a "textura intricata" with "hyphae widely spaced and immersed in a gel" and a "gelatinized tissue, appearing to have widely spaced, parallel, thin-walled hyphae probably arising by gelatinization of the thick walls of an earlier textura oblita", and depicted them. Similarly, Breitenbach and Kränzlin 
Fig. 5 Hymenoscyphus fructigenus var. carpini. a Habitus. b Textura porrecta typica in the medullary excipulum. c Textura prismatica typica in the ectal excipulum. Drawing and photographs by the author (coll. J. Hengstmengel no. 443;

28.9.1979; Netherlands, Leiden, Botanical garden; on fallen fruits of Carpinus betulus; herb. L 977.215-219)

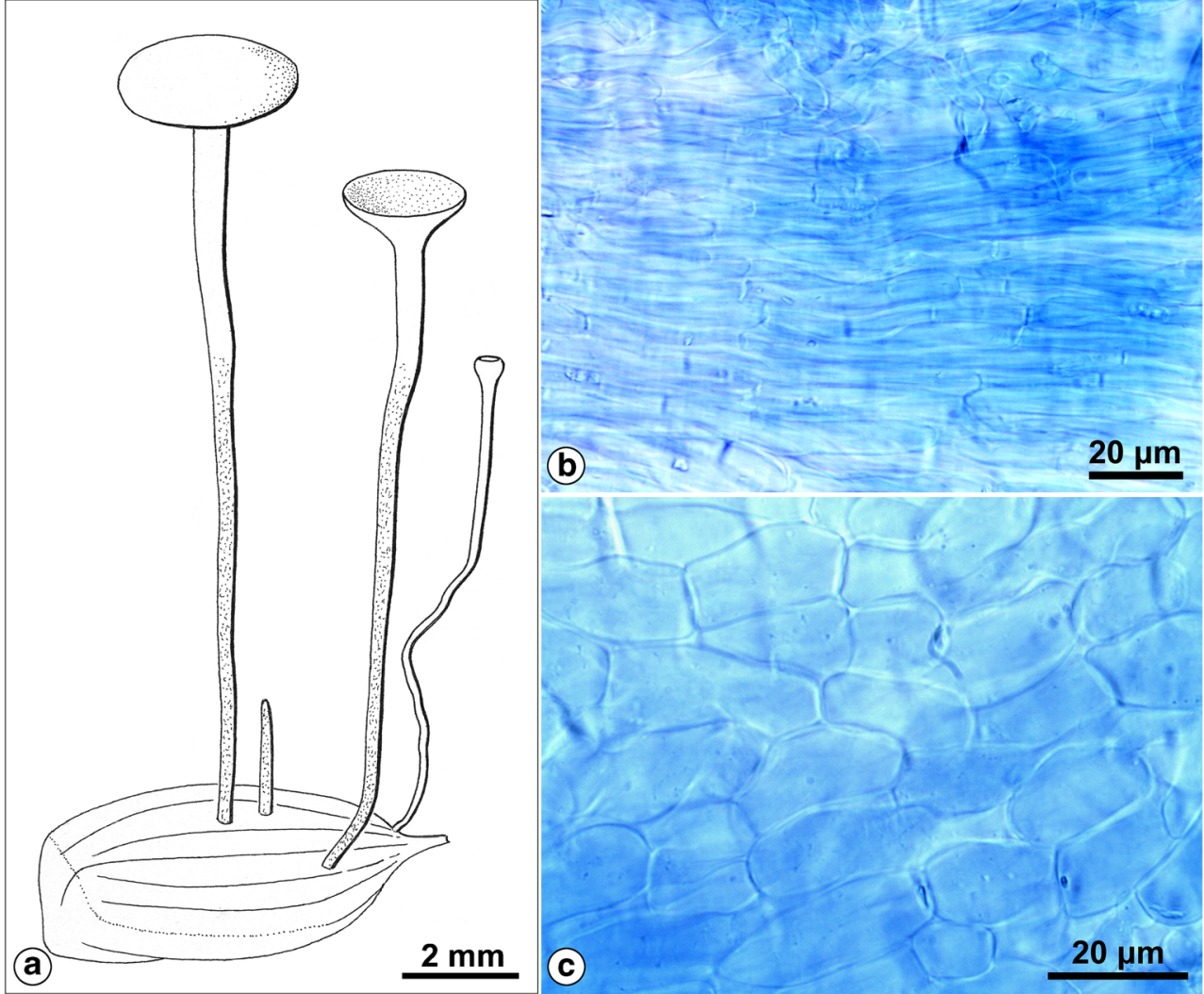

(1981: Abb. 7, bottom figure) give a diagram of "gelatinisiertes Gewebe" with thin, winding hyphae surrounded by gel. Apparently, the latter three authors felt the need to illustrate these gelatinized tissues because the current tissue type terminology and illustrations did not cover this clearly.

Gelatinization may occur in different fungal tissue types. For instance, whereas the latter three authors indicate the existence of a gelatinized textura intricata, Carpenter (1981) mentions a tissue of "long-celled, subparallel [...] hyphae immersed in a gelatinous matrix", so a gelatinized textura porrecta. This means that "gel(atinous) tissue" sensu Moore cum suis is a collective noun concerning tissues in which a gelatinous matrix has developed and which may be classified according to their structure and origin. Analogously, incrassate hyphal or cell walls are not limited to one particular tissue type, especially textura oblita sensu Starbäck or Korf, but may also occur in, e.g., textura prismatica. Thus, we might speak of a gelatinous and an incrassate version of basic tissue types, occasionally combined. Incrassate tissues are not a "gelatinous tissue" unless the hyphae are embedded in a gel matrix. The consistency of the swollen hyphal walls is not defined: they may be firm and nontransparent or more gelatinous and glassy.

Ideally a tissue typology should be used which is based on basic tissue types and in which the different versions can be expressed. For the sake of efficiency, any version of a tissue type should be provided with a significant name. Addition of an adjective to the name of the basic type might be a simple
Fig. 6 Cyathicula starbaeckii. a Habitus. b Textura porrecta imbuta in ectal excipulum. Photographs by L.C.A.F. Rommelaars (coll. L.C.A.F. Rommelaars s.n.; 15.9.2012; Netherlands, Udenhout, "De Nieuwe Tiend"; on dying stemlets of Ranunculus; herb. Rommelaars)
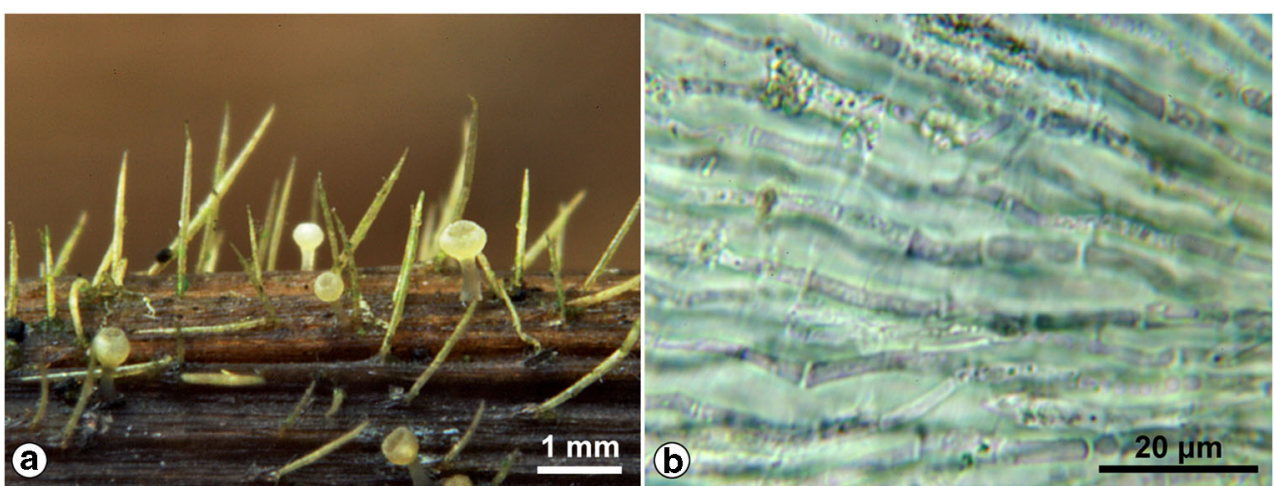
Fig. 7 Hymenoscyphus imberbis. a Habitus. b Textura intricata typica in medullary excipulum. Photographs by L.C.A.F.

Rommelaars (coll. L.C.A.F.

Rommelaars s.n.; 2013;

Netherlands, Tilburg,

"Kaaistoep"; on dead deciduous wood; herb. Rommelaars)

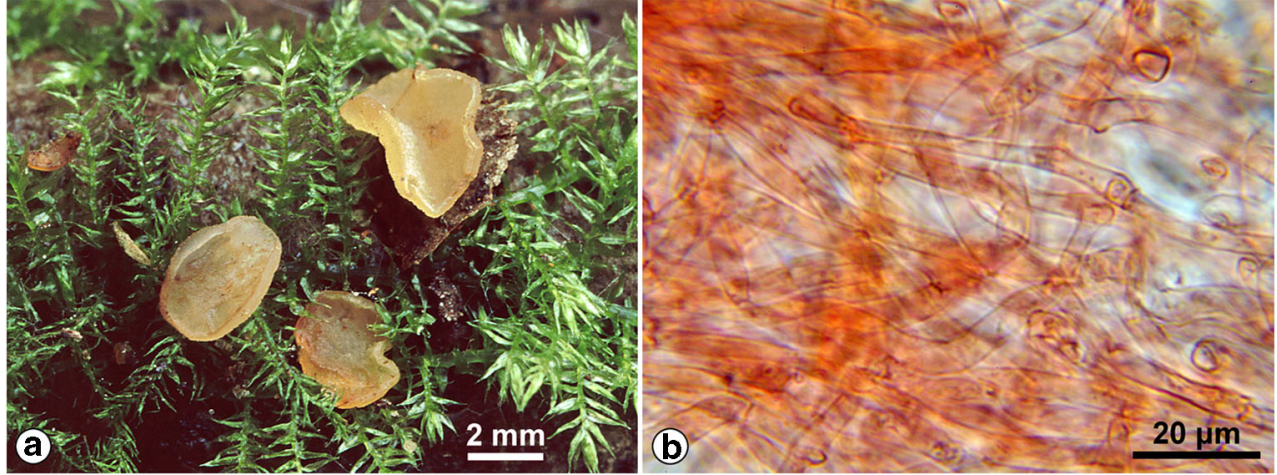

method to provide for that, e.g., "typica" for the primitive version, "incrassata" for the derived version with thickwalled hyphae and "imbuta" (= embedded, imbued) for the derived version with hyphae embedded in a gel. Because of the outlined confusion in correctly applying the term "gel(atinous) tissue", it seems better to avoid the use of an adjective "gelatinosa". Of course the development from the primitive version to a derived version is a gradual process, so that also transitional stages may be observed. Moreover, intermediate forms between "basic" tissue types exist. It is needless to say that also the proposed classification is a simplification of reality but that does not make it less useful.

In my opinion, textura oblita is not a basic textura type. In accordance with their definitions, textura oblita sensu Korf may be regarded as a textura porrecta with incrassate cell walls and narrowed lumina, textura oblita sensu Carpenter as a textura porrecta with thin-walled hyphae immersed in gel, and textura oblita sensu Starbäck as a textura porrecta with incrassate-walled hyphae immersed in gel. So all three conceptions of textura oblita can be reduced to particular versions of textura porrecta, namely, an incrassate, an embedded, and an incrassate-embedded version.

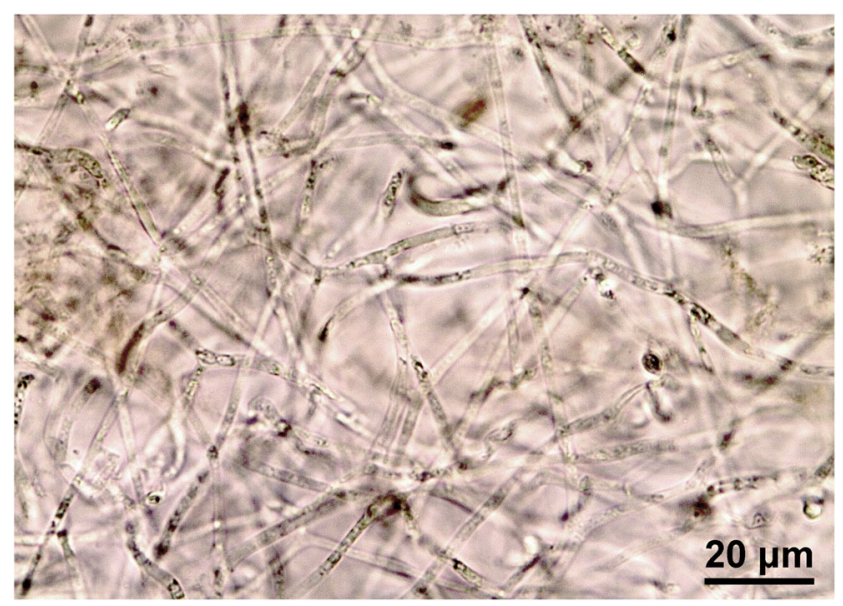

Fig. 8 Bulgaria inquinans. Textura intricata imbuta in medullary excipulum. Photograph by the author (coll. J. Hengstmengel no. 560; 27.10.2016; Netherlands, Breukelen, "Gunterstein"; on bark of dead logs of Quercus robur; herb. L.4314472)

\section{Synopsis}

In conclusion, an emended tissue typology system is presented in which the primitive versions of the six basic tissue types together with ten derived versions and two combinations of derived versions are arranged according to the shape of their cells, the arrangement of their hyphae, the occurrence of thickened cell walls, and the occurrence of extracellular gel. The basic types 1-5 are based on Starbäck (1895), type 6 is based on Korf (1951). They have slightly been emended here.

1. Textura porrecta: Tissue composed of relatively long-celled and slender, more or less parallel, cylindrical hyphae.

1.1. Textura porrecta typica (Figs. $5 \mathrm{~b}$ and 11a): Hyphae thin-walled, loosely lying together, with more or less interhyphal space filled with water.

This tissue type is very common in dry-fleshy ascocarps of, e. g., Helotiales. Illustrations of this tissue type can be found in many publications, e.g., Korf (1958: fig. 5g; 1973: fig. 3G), van Brummelen (1967: fig. 1), and Breitenbach and Kränzlin (1981: Abb. 7).

1.2. Textura porrecta incrassata (Fig. 11b): Hyphae cohering, without or with hardly any interhyphal space and without interhyphal substance; cells with (strongly) incrassate, often refractive walls and narrow lumina in comparison with the thickness of these walls; hyphal boundaries situated approximately in the middle of the wall substance between two mutually adjacent lumina.

This type is also shown in, e.g., Korf (1958: fig. 5f, reproduced here in fig. 3; 1973: fig. 3F) and van Brummelen (1967: fig. 1), in all these cases under the name "textura oblita". These figures, however, do not show that the thickened walls are segmented like the hyphal contents, while this just should be the case when the thickening material is within the cell wall. Obviously there is a relation between the swelling of the hyphal walls, at one side, and the 
Fig. 9 Hymenoscyphus epiphyllus var. acarius. a Habitus. b Textura globulosa typica in ectal excipulum. Photographs by L.C.A.F. Rommelaars (coll.

L.C.A.F. Rommelaars s.n.; 2012; Netherlands, Tilburg,

"Kaaistoep"; on mixture of Pinus sylvestris needles and deciduous leaves; herb. Rommelaars)
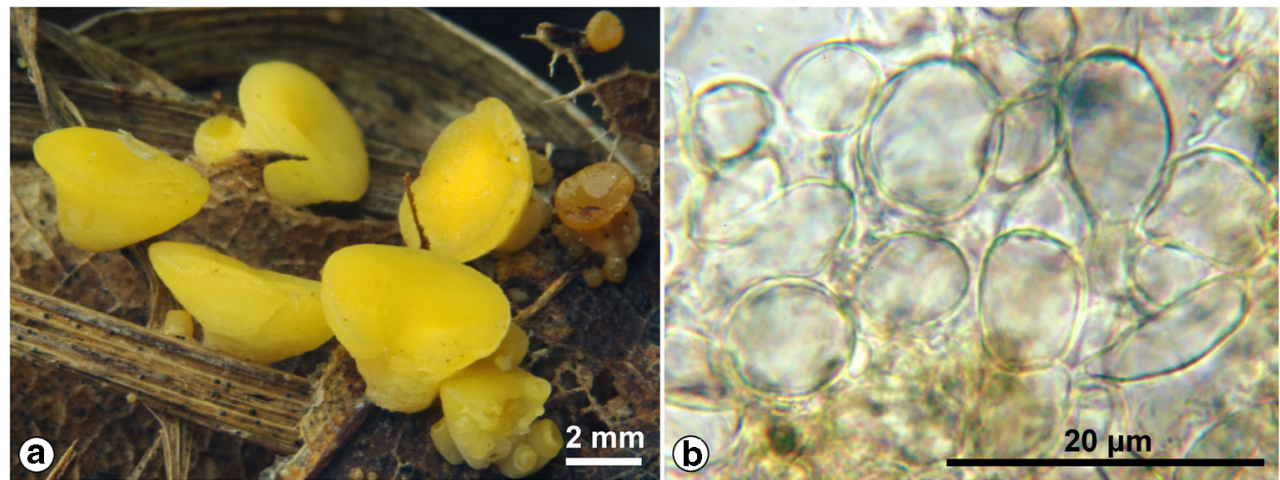

cohesion of the hyphae and the (relative) narrowness of the lumina, at the other side. Indeed, this swelling may act in two directions. Outwards it causes the hyphae to become closely packed together and becoming "cohering" (Korf 1951, 1958) or "agglutinated" (Korf 1973). Inwards it may cause the lumen to narrow. This change from textura porrecta typica into textura porrecta incrassata may also happen if dried sporocarps are soaked up for microscopic investigation and the cell walls, dependent on the medium used, are swelling up by water imbibition. Then a formerly firm-walled textura porrecta (in the living state) may appear as a textura porrecta incrassata in the dead state (Helleman et al. 2013, as textura oblita), so it is important to examine an apothecium in the living state when describing the textura types in its excipulum.

Textura porrecta incrassata occurs in various genera of discomycetes, e.g., Micropeziza Fuckel as redefined by Nannfeldt (1976, as textura oblita), and in the protruding collar of Godronia cassandrae (see Filippova at www.ascofrance.com/search_forum/ 21961 d.d. 17-02-2013 as textura oblita-gelatinosa). Also Hymenoscyphus dearnessii is illustrative for this nongelatinized tissue type with thickened, refractive hyphal walls (White 1944; Dumont 1981).
1.3. Textura porrecta imbuta (Figs. $6 \mathrm{~b}$ and $11 \mathrm{c}$ ): Interhyphal space filled with gel formed by secretion of the cells, so that the hyphae have become immersed in gel and-at least in a "complete gel matrix" - spaced more widely. Whereas the hyphae are transversally septated, the gel matrix is not so. This tissue type is very common in more or less gelatinous apothecia and hitherto often called "textura oblita", in contrast with its definition by Starbäck and Korf but in agreement with Carpenter's definition.

This type occurs in species of, e.g., Allophylaria, Crocicreas, Cyathicula (see Baral 2020: "Cyathicula on fern, 2.VIII.2017-3.jpg"), Rutstroemia (Hansen and Knudsen 2000: "hyphae embedded in a gelatinous matrix" resp. "gelatinized, long-celled hyphae"; Baral at www.ascofrance.com/search forum/2632 d.d. 0707-2007 - R. firma, as textura oblita), Torrendiella setulata (White 1941: "Rutstroemia" setulata - "hyphae thin-walled but imbedded in a non-staining gelatinous matrix"; Johnston et al. 2014: "cells immersed in abundant gel (textura oblita)"), Claussenomyces (Dixon 1974a: key option 12; Baral 2005: C. atrovirens, H.B. 5019, as textura oblita), and Chloroscypha (Carpenter 1981). In many species of the latter two genera, there is extracellular gel in the hymenium too, especially around the paraphyses
Fig. 10 Pyrenopeziza rubi. a Habitus. b Textura angularis typica in the ectal excipulum. Drawing by C. Bas, photograph by the author (coll. C. Bas no. 1442; 3.6.1958; Netherlands, Oegstgeest, "Oud-Poelgeest"; on dead, 3-year old stems of Rubus idaeus; herb. L 958.021-363)

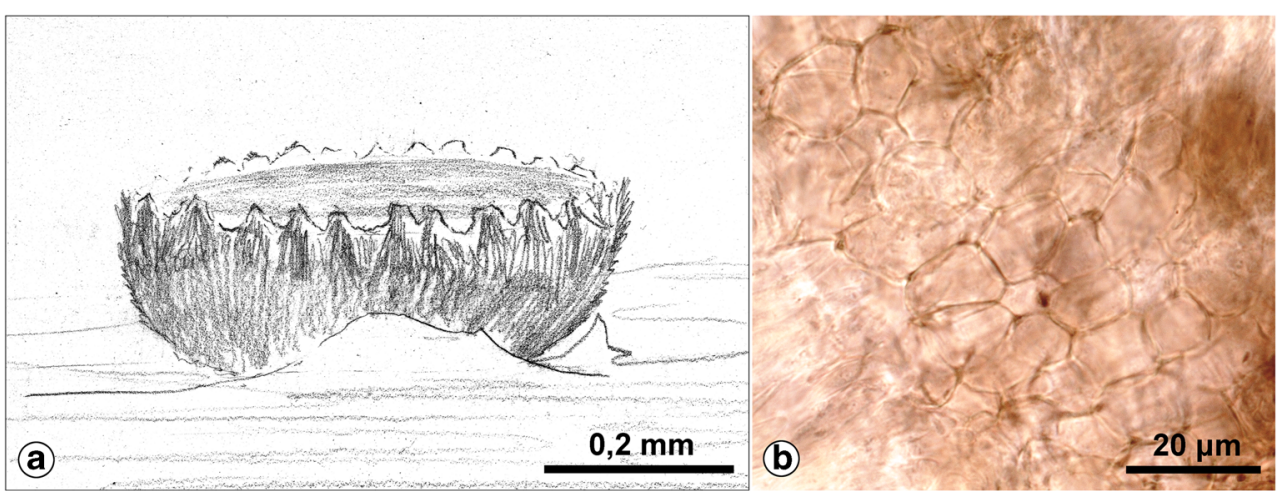



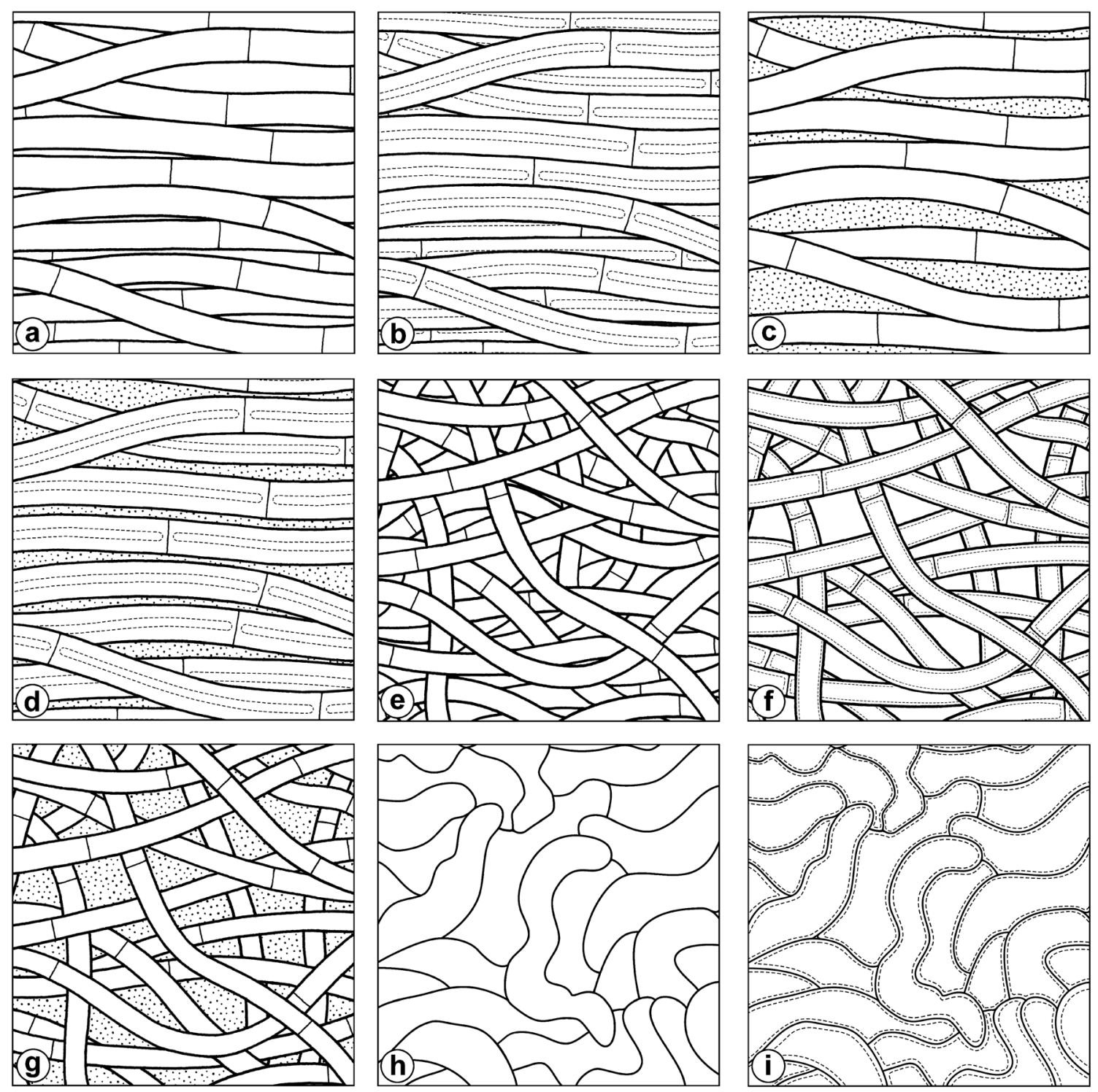

Fig. 11 Long-celled excipular tissue types in different versions, viewed in radial section $(\mathrm{a}-\mathrm{g})$ or surface view $(\mathrm{h}-\mathrm{i})$. a Textura porrecta typica. $\mathbf{b}$ Textura porrecta incrassata. $\mathbf{c}$ Textura porrecta imbuta. d Textura porrecta incrassato-imbuta. e Textura intricata typica. $\mathbf{f}$ Textura intricata incrassata.

g Textura intricata imbuta. h Textura epidermoidea typica. i Textura epidermoidea incrassata. Every square equals $50 \times 50 \mu \mathrm{m}$. Drawings by Esmée Winkel

(Dennis 1956b; Carpenter 1981; Baral 2020: Chloroscypha alutipes, H.B. 5366, Chloroscypha sabinae, H.B. 3873a, H.B. 5367). Other examples can be found in the ectal excipulum of Discinella menziesii sensu Boudier (Wieschollek et al. 2011: Abb. 6g), "Helotium" dicrani sensu Henderson (see "Introduction" section), and Hymenoscyphus honshuanus Baral (Baral and Bemmann 2014: fig. 12). In the latter publication, the excipular cells are called "with seemingly strongly gelatinized walls" but the drawing shows a gelatinous matrix.

Transitions between types 1.1 and 1.3 are reported in the provisional descriptions of type material of Peziza (Calycina, Pezizella) parilis P. Karst. (Baral
2020: Calycina parilis, H.B. 5018) and Peziza (Orbilia) diaphanula Cooke (Baral 2005: Calycellina diaphanula, H.B. 5755).

1.4. Textura porrecta incrassato-imbuta (Fig. 11d): Cells with (strongly) incrassate walls and at the same time immersed in an extracellular gel; hyphae more or less widely spaced. Actually this is what Starbäck (1895) described as textura oblita because here is an "intercellular substance" present among the long-celled, more or less parallel running thickwalled hyphae.

This textura type appears to be uncommon. Examples can be found in some species of the heterogeneous genus Bisporella Sacc. 

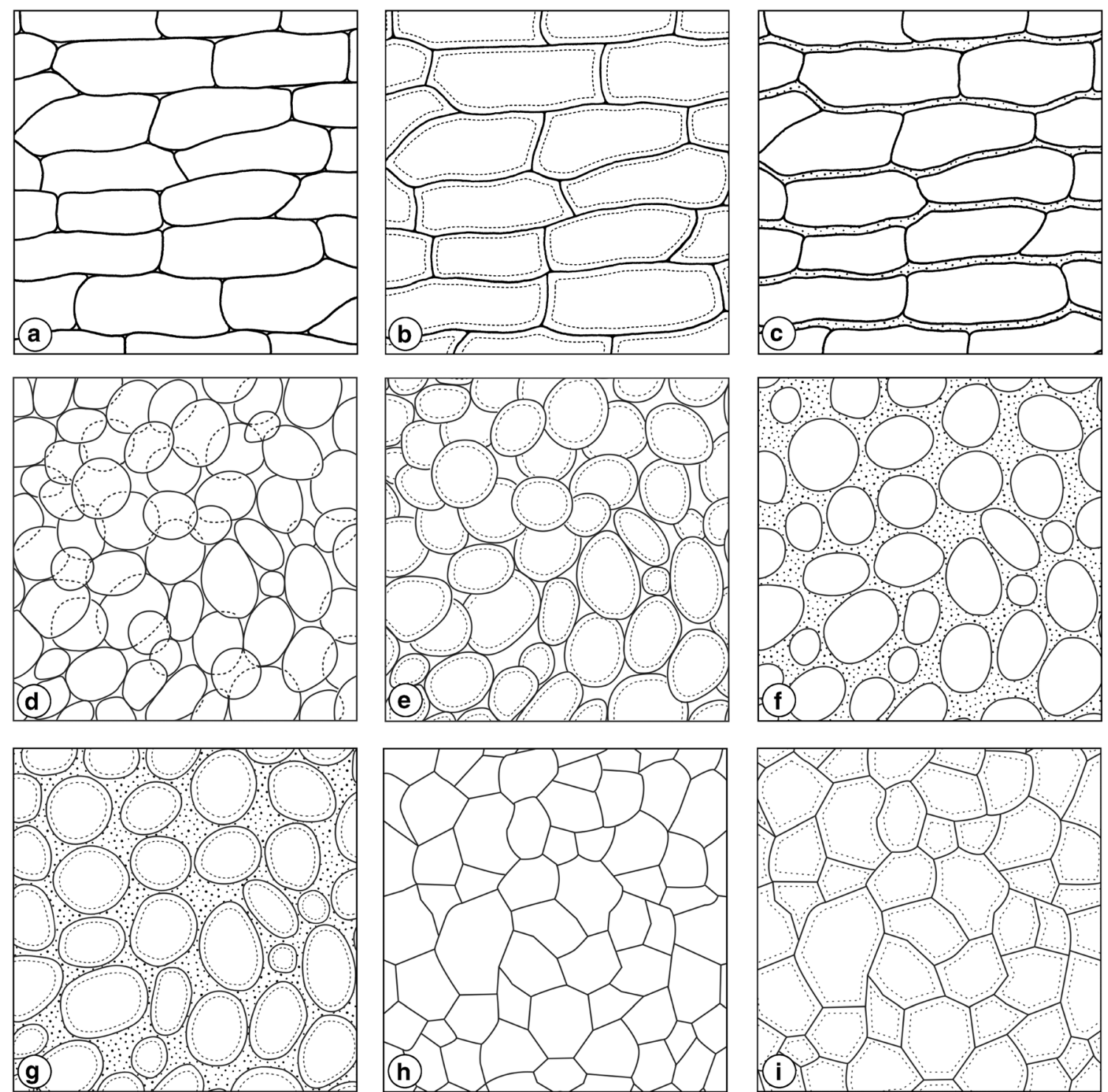

Fig. 12 Short-celled excipular tissue types in different versions, viewed imbuta. g Textura globulosa incrassato-imbuta. h Textura angularis typica. i Textura angularis incrassata. Every square equals $50 \times 50 \mu \mathrm{m}$. Drawings by Esmée Winkel (a-c) and Erik-Jan Bosch (d-i)

Textura prismatica incrassata. c Textura prismatica imbuta. d Textura globulosa typica. e Textura globulosa incrassata. f Textura globulosa

As stated before, in Korf's key, this genus (under the synonym Calycella) was keyed out by its feature that the hyphae or cells of the ectal excipulum have thickened, glassy walls which finally become a refractive gel in which the hyphal lumina are embedded (Korf 1973: key option 167), so as a case of disintegration of walls to form gel. Carpenter (1981), however, found the outer ectal excipulum in Bisporella composed of compact, interwoven, thick-walled hyphae immersed in a gel, as a result of excretion of gel. He could not have seen this distinction between gelatinized cell walls and extracellular gel, separated by the outer layer of the hyphal wall, if the gel would have been the result of disintegration of the wall. Zhuang et al. (2017) say that the ectal excipulum in Bisporella is strongly gelatinous and consists of textura oblita, textura angularis, or textura intricata. This suggests the latter two tissue types to be thin-walled and the first one, occurring in, e.g., B. magnispora and shangrilana, to be thick-walled, according to the current definition of textura oblita.

2. Textura intricata: Tissue composed of relatively long-celled and slender, loosely interwoven, cylindrical hyphae.

2.1. Textura intricata typica (Figs. $7 \mathrm{~b}$ and $11 \mathrm{e}$ ): Hyphae thin-walled, with interhyphal spaces filled with air. 
This tissue type has been illustrated by several authors, e.g., Korf (1958: fig. 5d; 1973: fig. 3D), van Brummelen (1967: fig. 1), and Breitenbach and Kränzlin (1981: Abb. 7).

It occurs especially in relatively soft-fleshy or juicy but non-gelatinous ascocarps, e.g., in Phaeohelotium and Sarcoleotia. This juicy consistency is caused by the fact that textura intricata has a spongy structure which can easily take in and hold water in the interhyphal spaces. For this reason, moist ascocarps at first sight may seem to have the consistency of a Leotia, but by microscopical examination, no interhyphal gel is found (e.g., Gotink and Helleman 2016).

2.2. Textura intricata incrassata (Fig. 11f): Cells with thickened, often refractive walls.

An example of this type can be found in Chlorociboria (Le Gal 1953: fig. 161 - drawing; Korf 1958: fig. 8 - drawing; Dixon 1974a: key option 12'; Dixon 1974b; Johnston and Park 2005). Chlorociboria can, indeed, also contain other textura types with incrassate cell walls.

2.3. Textura intricata imbuta (Figs. 8 and $11 \mathrm{~g}$ ): Interhyphal space filled with gel formed by secretion of the cells. Also in this tissue type, the gel may have caused a displacement of the hyphae, in the sense that the hyphae may have become more widely spaced in the gelatinous matrix.

This tissue type was earlier illustrated by Korf (1973: fig. 3 H1) and Breitenbach and Kränzlin (1981: Abb. 7), by the latter under the name "gelatinisiertes Gewebe."

It occurs in the medullary excipulum of, e.g., Ascocoryne, Ombrophila, and Neobulgaria species (Carpenter 1981), Encoelia toomansis (Dennis 1958), and Claussenomyces pleomorphicus (Gamundi and Giaiotti 1995), and in the outer excipulum of Pezoloma species.

3. Textura epidermoidea: A long-celled, usually membranaceous tissue composed of irregularly meandering, interlocking cells like jigsaw pieces with united walls, without clear hyphal arrangement and without interhyphal spaces.

3.1. Textura epidermoidea typica (Fig. 11h): Cells with thin walls.

This tissue type was illustrated by, e.g., Korf (1958: fig. 5e; 1973: fig. 3E), van Brummelen (1967: fig. 1), and Breitenbach and Kränzlin (1981: Abb. 7).

It occurs in the ectal excipulum of, e.g., Antinoa fumosellina, Crumenula linnaeae (Starbäck 1895), and Tapesina griseovitellina (Korf 1951). In the latter, intermediates between textura angularis typica and a textura epidermoidea typica occur as well.

3.2. Textura epidermoidea incrassata (Fig. 11i): Cells with incrassate walls.

The ectal excipula of Chlorociboria aeruginosa and C. aeruginascens (Korf 1958; Dixon 1974b) show this type.

4. Textura prismatica: Tissue composed of relatively shortcylindrical cells which are more or less rectangular (brickshaped) in side view and are lying in more or less parallel rows. These rows actually represent the hyphae but they can be difficult to distinguish.

4.1 Textura prismatica typica (Figs. 5c and 12a): Cells thin-walled; interhyphal space filled with air.

This tissue type has been illustrated by several authors, e.g., Korf (1958: fig. 5c; 1973: fig. 3C), van Brummelen (1967: fig. 1), and Breitenbach and Kränzlin (1981: Abb. 7), as it is very common in discomycetes, especially in the outer layer of the excipulum.

4.2. Textura prismatica incrassata (Fig. 12b): Cells with incrassate walls, possibly with less interhyphal space. Korf (1951) called this tissue type in some cases "textura prismatica with gelatinized, thick walls", and in others a "gelatinized textura prismatica".

This tissue type occurs in, e.g., the ectal excipulum of Tapesina griseovitellina (Korf 1951) and Micropeziza curvatispora (Lindemann et al. 2014, as "more of less thick-walled textura prismatica" so gradually different from textura prismatica), and in species of Chlorociboria (Johnston and Park 2005) and Arachnopeziza (Korf 1951).

4.3. Textura prismatica imbuta (Fig. 12c): Interhyphal space filled with gel formed by secretion of the cells, so that the cell rows may have become more widely spaced immersed in gel.

This tissue is present in, e.g., the ectal excipulum of "Bryoscyphus" dicrani non sensu Spooner (see "Introduction" section), Dumontinia tuberosa (see www.ambmuggia.it/forum/topic/8903-dumontiniatuberosa/), Perrotia flammea (Baral 1987; Baral 2020: P. flammea, H.B. 3146), and Lachnellula species, and in other genera of Hyaloscyphaceae (Baral 1987, 2008; photograph in www. asturnatura.com/fotografia/setas-hongos/ lachnellula-resinaria-var-calycina-sacc-baral-3/ 17976.html). 
5. Textura globulosa: Tissue composed of more or less isodiametrical, spherical cells without clear hyphal arrangement.

5.1 Textura globulosa typica (Figs. 9b and 12d): Cells thin-walled cells; intercellular spaces filled with water.

This tissue type was illustrated by Korf (1958: fig. 5a; 1973: fig. 3A), van Brummelen (1967: fig. 1), and Breitenbach and Kränzlin (1981: Abb. 7).

Examples of this tissue type can be found in the ectal excipulum of, e.g., Phaeohelotium, Ombrophila, Ciboria, and Mollisia. Intermediate forms between this type and textura angularis typica may occur.

In the last four decades, instead of "textura globulosa" often the shortened term "textura globosa" is used, e.g., by Pearce and Hyde (2001). However, strictly speaking this term does not appear to be defined.

5.2. Textura globulosa incrassata (Fig. 12e): Cells with incrassate walls.

This textura type occurs in the ectal excipulum of, e.g., Chlorociboria (Dixon 1974b), Naeviopsis, and Ploettnera (Nauta and Spooner 1999).

5.3. Textura globulosa imbuta (Fig. 12f): Interhyphal space filled with gel formed by secretion of the cells.

This tissue type occurs in the ectal excipulum of, e.g., Lachnellula robusta (Baral 2008), in this case with transitions to longer-celled gelatinized tissue and therefore called "textura globulosa-oblita".

5.4. Textura globulosa incrassato-imbuta (Fig. 12g): Cells with incrassate walls and at the same time immersed in an extracellular gel.

Examples of this textura type can be found in the margin of apothecia of Micropeziza poae (Nauta and Spooner 2000) and in the ectal excipulum of Bisporella iodocyanescens (Zhuang et al. 2017).

6. Textura angularis: Tissue composed of tightly packed, more or less isodiametrical, polyhedral cells, without intercellular spaces; the polyhedral shape of the cells and the absence of interhyphal spaces appear to be caused by expansion and mutual pressure of the cells.

6.1. Textura angularis typica (Fig. $10 \mathrm{~b}$ and $12 \mathrm{~h}$ ): Cells thin-walled.

Korf (1958: Fig. 5b; 1973: Fig. 3B), van Brummelen (1967: Fig. 1), and Breitenbach and Kränzlin (1981: Abb. 7) also illustrated this textura type.

Examples can be found in the ectal excipulum of species of, e.g., Hysteropezizella, Pyrenopeziza, and other genera of Dermateaceae (Nauta and Spooner 2000).

6.2. Textura angularis incrassata (Fig. 12i): Cells with incrassate walls.

This tissue type can be found in, e.g., Arachnopeziza (Korf 1951) and Coryne tasmanica (Dennis 1958), in the former also intermediates with regard to textura prismatica incrassata. The ectal excipulum in Chlorociboria species can comprise different textura types with thickened, gelatinous walls including the present one (Dixon 1974b; Johnston and Park 2005).

This typology is an emended classification based on the outcome of a literature review, but agrees fully with my own observations. I am interested in the opinion of the readers about this arrangement.

Acknowledgments I am very grateful to Luciën Rommelaars for providing the photographs of Figs. 6, 7, and 9, to Esmée Winkel MSI (Naturalis Biodiversity Center) for making the drawings of Figs. $11 \mathrm{a}-\mathrm{i}$ and $12 \mathrm{a}-\mathrm{c}$, to Erik-Jan Bosch (Naturalis Biodiversity Center) for making the drawings of Figs. $12 \mathrm{~d}-\mathrm{i}$, to the heirs of Prof. Richard P. Korf and to The New York Botanical Garden Press for their permission to reproduce Fig. 3 resp. 4, to the directors of Naturalis Biodiversity Center and Hortus Botanicus Leiden for the offered facilities, and to Else C. Vellinga for her presubmission review and linguistic advice.

Open Access This article is licensed under a Creative Commons Attribution 4.0 International License, which permits use, sharing, adaptation, distribution and reproduction in any medium or format, as long as you give appropriate credit to the original author(s) and the source, provide a link to the Creative Commons licence, and indicate if changes were made. The images or other third party material in this article are included in the article's Creative Commons licence, unless indicated otherwise in a credit line to the material. If material is not included in the article's Creative Commons licence and your intended use is not permitted by statutory regulation or exceeds the permitted use, you will need to obtain permission directly from the copyright holder. To view a copy of this licence, visit http://creativecommons.org/licenses/by/4.0/.

\section{References}

Albuquerque PC, Nakayasu ES, Rodriques ML, Frases S, Casadevall A, Zancope-Oliveira RM, Almeida IC, Nosanchuk JD (2008) Vesicular transport in Histoplasma capsulatum: an effective mechanism for trans-cell wall transfer of proteins and lipids in ascomycetes. Cell Microbiol 10:1695-1710. https://doi.org/10.1111/j.1462-5822. 2008.01160.x

Bandoni RJ, Bisalputra AA (1971) Budding and fine structure of Tremella mesenterica haplonts. Can J Bot 49:27-30. https://doi. org/10.1139/b71-005

Baral HO (1987) Lugol's solution/IKI versus Melzer's reagent: hemiamyloidity, a universal feature of the ascus wall. Mycotaxon 29:399-450

Baral HO (2005) In vivo veritas. 3rd edn. Published on DVD

Baral HO (2008) Dichotomous key to Lachnellula (worldwide) (Trichoscyphelloideae, Lachnaceae, Helotiales, Ascomycetes), with 
a synoptic table of characters. https:/in-vivo-veritas.de/wp-content/ uploads/2015/10/Lachnellula-Baral-20081.pdf

Baral HO (2020) In vivo veritas-Ascomycetes illustrations. https://invivo-veritas.de/ascomycetes-illustrations

Baral HO, Bemmann M (2014) Hymenoscyphus fraxineus vs. Hymenoscyphus albidus - a comparative light microscopic study on the causal agent of European ash dieback and related foliicolous, stroma-forming species. Mycology 5:228-290. https://doi.org/10. 1080/21501203.2014.963720

Bartnicki-Garcia S (1968) Cell wall chemistry, morphogenesis, and taxonomy of fungi. Annu Rev Microbiol 22:87-108. https://doi.org/10. 1146/annurev.mi.22.100168.000511

Breitenbach J, Kränzlin F (1981) Pilze der Schweiz. Beitrag zur Kenntnis der Pilzflora der Schweiz. Band 1: Ascomyceten (Schlauchpilze). Mykologia, Luzern

Brown L, Wolf JM, Prados-Rosales R, Casadevall A (2015) Through the wall: extracellular vesicles in Gram-positive bacteria, mycobacteria and fungi. Nat Rev Microbiol 13:620-630. https://doi.org/10.1038/ nrmicro3480

Carpenter SE (1980) New combinations in Crocicreas Fr. emend. SE Carpenter (Discomycetes, Helotiales). Brittonia 32:269-271

Carpenter SE (1981) Monograph of Crocicreas (Ascomycetes, Helotiales, Leotiaceae). Mem N Y Bot Gard 33:1-290

Casadevall A, Nosanchuk JD, Williamson P, Rodrigues ML (2009) Vesicular transport across the fungal cell wall. Trends Microbiol 17:158-162. https://doi.org/10.1016/j.tim.2008.12.005

de Bary A (1884) Vergleichende Morphologie und Biologie der Pilze, Mycetozoen und Bacterien. Engelmann, Leipzig. https://doi.org/10. 5962/bhl.title.42380

Dennis RWG (1956a) Two species of Helotiaceae with gelatinised surface tissues. Kew Bull 10:567-569. https://doi.org/10.2307/ 4113761

Dennis RWG (1956b) A revision of the British Helotiaceae in the herbarium of the Royal Botanic Gardens, Kew, with notes on related European species. Mycol Pap 62:1-216

Dennis RWG (1958) Critical notes on some Australian Helotiales and Ostropales. Kew Bull 13:321-358. https://doi.org/10.2307/4109542

Dixon JR (1974a) Chlorosplenium and its segregates. I Introduction and the genus Chlorosplenium. Mycotaxon 1:65-104

Dixon JR (1974b) Chlorosplenium and its segregates. II The genera Chlorociboria and Chlorencoelia. Mycotaxon 1:193-237

Döbbeler P (1978) Moosbewohnende Ascomyceten I: Die pyrenocarpen, den Gametophyten besiedelnden Arten. Mitt Bot München 14:1360. https://www.zobodat.at/pdf/Mitt-Bot-StaatsS-Muenchen_14_ 0001-0360.pdf

Dumont KP (1981) Leotiaceae III: notes on selected temperate species referred to Helotium and Hymenoscyphus. Mycotaxon 13:59-84

Gamundi IJ, Giaiotti AL (1995) A new species of Claussenomyces (Helotiales) from southern South America. N Z J Bot 33:513-517. https://doi.org/10.1080/0028825X.1995.10410622

Gehrmann U, Qazi KR, Johansson C, Hultenby K, Karlsson M, Lundeberg L, Gabrielsson S, Scheynius A (2011) Nanovesicles from Malassezia sympodialis and host exosomes induce cytokine responses - novel mechanisms for host-microbe interactions in atopic eczema. PLoS One 6:e21480. https://doi.org/10.1371/journal. pone. 0021480

Gotink M, Helleman S (2016) Sarcoleotia platypus, onder een andere naam weer terug van weggeweest. Coolia 59:15-17

Gow NAR, Latgé J-P, Munro CA (2017) The fungal cell wall: structure, biosynthesis, and function. Microbiol Spectrum 5:1-25. https://doi. org/10.1128/microbiolspec.FUNK-0035-2016

Hansen L, Knudsen H (eds) (2000) Nordic macromycetes, 1: Ascomycetes. Nordsvamp, Copenhagen

Helleman S, Lindemann U, Baral HO, Yeates C (2013) Micropeziza filicina sp. nov. (Helotiales), a fern inhabiting species of intermediate generic position, with an emendation of the genus Micropeziza Fuckel. https://www.Ascomycete.org 5:129-136

Henderson DM (1972) Fungi on Scottish bryophytes. Trans Bot Soc Edinb 41:385-391. https://doi.org/10.1080/03746607208685240

Hibbett DS (2007) Agaricomycotina: jelly fungi, yeasts, and mushrooms. Version 20 April 2007. http://tolweb.org/Agaricomycotina/20531/ 2007.04.20 in: The tree of life web project, http://tolweb.org/

Ingold CT (1959) Jelly as a water-reserve in fungi. Trans Br Mycol Soc 42:475-478. https://doi.org/10.1016/S0007-1536(59)80048-6

Iturriaga T, Korf RP, Babcock JF (1999) Fungi on Epifagus: Crocicreas epifagicola sp. nov., with comments on the generic names Crocicreas and Cyathicula. Mycol Res 103:28-30. https://doi.org/ 10.1017/S0953756298007060

Johnston PR, Park D (2005) Chlorociboria (Fungi, Helotiales) in New Zealand. N Z J Bot 43:679-719. https://doi.org/10.1080/0028825X. 2005.9512985

Johnston PR, Park D, Baral HO, Galán R, Platas G, Tena R (2014) The phylogenetic relationships of Torrendiella and Hymenotorrendiella gen. nov. within the Leotiomycetes. Phytotaxa 177:1-25. https://doi. org/10.11646/phytotaxa.177.1.1

Kirk PM, Cannon PF, Minter DW, Stalpers JA (eds) (2008) Ainsworth \& Bisby's dictionary of the fungi. 10th edn. CAB International, Wallingford (UK)

Korf RP (1951) A monograph of the Arachnopezizeae. Lloydia 14:129180

Korf RP (1958) Japanese discomycete notes I-VIII. Sci Rep Yokohama Natl Univ, Sect II 7:7-35

Korf RP (1973) Discomycetes and Tuberales. In: Ainsworth GC, Sparrow FK, Sussman AS (eds) The fungi: an advanced treatise, IVA: 249-319. Academic Press, New York/London

Kreger-van Rij NJW, Veenhuis M (1971) A comparative study of the cell wall structure of basidiomycetous and related yeasts. J Gen Microbiol 68:87-95. https://doi.org/10.1099/00221287-68-1-87

Le Gal M (1953) Les Discomycètes de Madagascar. Laboratoire de Cryptogamie du Muséum National d'Histoire Naturelle, Paris

Lindemann U, Helleman S, Filippova N, Krieglsteiner L, Pennanen M (2014) Micropeziza curvatispora sp. nov., M. fenniae sp. nov. and M. zottoi sp. nov. (Helotiales) - three new species of the genus Micropeziza from Western Siberia, Finland, Germany and Belgium. https://www.Ascomycete.org. 6:113-124

Malloch D (2019) Natural history of fungi. A part of the Mycology Web Pages, New Brunswick Museum. http://website.nbm-mnb.ca/ mycologywebpages/NaturalHistoryOfFungi/JellyFungi.html

Mitchell KF, Zarnowski R, Andes DR (2016) Fungal super glue: the biofilm matrix and its composition, assembly, and functions. PLoS Pathog 12:e1005828. https://doi.org/10.1371/journal.ppat.1005828

Moore EJ (1965a) Fungal gel tissue ontogenesis. Am J Bot 52:389-395. https://doi.org/10.1002/j.1537-2197.1965.tb06799.x

Moore EJ (1965b) Staining fungal gel with mucin techniques. Stain Technol 40:23-27

Moore EJ (1965c) Ontogeny of gelatinous fungi. Mycologia 57:114-130. https://doi.org/10.1080/00275514.1965.12018197

Moore RT (1978) Taxonomic significance of septal ultrastructure with particular reference to the jelly fungi. Mycologia 60:1007-1024. https://doi.org/10.2307/3759134

Moore-Landecker E (1981) Histochemical observations on the discomycete, Pyronema domesticum, with special reference to apothecial ontogeny. Mycologia 73:301-320. https://doi.org/10.1080/ 00275514.1981.12021347

Nannfeldt JA (1932) Studien über die Morphologie und Systematik der nicht-lichenisierten inoperculaten Discomyceten. Nova Act Soc Sci upsal, ser IV, 8:1-368, Tafel I-XX

Nannfeldt JA (1976) Micropeziza Fuck. and Scutomollisia Nannf. nov. gen. (Discomycetes inoperculati). Bot Notiser 129:323-340, Tafel I-XX 
Nauta MM, Spooner B (1999) British Dermateaceae: 2 Naevioideae. Mycologist 13:65-69. https://doi.org/10.1016/S0269-915X(99) 80010-X

Nauta MM, Spooner B (2000) British Dermateaceae: 4B Dermateoideae genera G-Z. Mycologist 14:65-74. https://doi.org/10.1016/S0269915X(00)80007-5

Pearce CA, Hyde KD (2001) Two new genera in the Phyllachoraceae: Sphaerodothella to accommodate Sphaerodothis danthoniae, and Parberya gen. nov. Fungal Divers 6:83-97

Plopper G (2007) The extracellular matrix and cell adhesion. In: Lewin B et al. (eds) Cells: 645-702. Jones and Bartlett Publishers, Sudbury, MA

Quijada L, Ribes M, Negrín R, Beltrán-Tejera E (2017) Lignicolous species of Helotiales associated with major vegetation types in the Canary Islands. Willdenowia 47:271-291. https://doi.org/10.3372/ wi.47.47310

Rieger R, Michaelis A, Green MM (1991) Glossary of genetics: classical and molecular, 5th edn. Springer-Verlag, Berlin etc

Rodrigues ML, Nimrichter L, Oliveira DL, Frases S, Miranda K, Zaragoza O, Alvarez M, Nakouzi A, Feldmesser M, Casadevall A (2007) Vesicular polysaccharide export in Cryptococcus neoformans is a eukaryotic solution to the problem of fungal transcell wall transport. Eukaryot Cell 6:48-59. https://doi.org/10.1128/ EC.00318-06

Rubio Domínguez E (2013) Antinoa strobilina (Fr.) Velen., 1934. Asturnatura.com, nr. 407, 13/01/2013. https://www.asturnatura. com/especie/antinoa-strobilina.html

Schultzhaus ZS, Shaw BD (2015) Endocytosis and exocytosis in hyphal growth. Fung Biol Rev 29:43-52. https://doi.org/10.1016/j.fbr. 2015.04.002

Spooner BM (1984) Ascomycetes. In: Kirk PM, Spooner BM, An account of the fungi of Arran, Gigha and Kintyre. Kew Bull 38:548 576. https://doi.org/10.2307/4108573

Srivastava KC, Smith DG (1974) Electron microscopy of a psychrophilic yeast, Candida gelida. Micron 5:191-199

Starbäck K (1895) Discomyceten-Studien. Bih K svenska Vetensk-Akad Handl 21, afd 3, no 5: 1-42, Tafel I-II. https://www. biodiversitylibrary.org/page/14151080

Tholl MT, Baral HO, Schultheis B, Marson G, Diederich P (2000) Journées luxembourgeoises de mycology vernale 1998. Bull Soc Nat luxemb 100:39-62
Ulrich R (1943) Les constituants de la membrane chez les champignons. Rev Mycol Mém hors-série 3:1-44

Vallejo MC, Nakayasu ES, Longo LVG, Ganiko L, Lopes FG, Matsuo AL, Almeida IC, Puccia R (2012) Lipidomic analysis of extracellular visicles from the pathogenic phase of Paracoccidioides brasiliensis. PLoS One 7:e39463. https://doi.org/10.1371/journal. pone. 0039463

van Brummelen J (1967) A world-monograph of the genera Ascobolus and Saccobolus (Ascomycetes, Pezizales). Persoonia - Suppl 1:1-260

van der Klei I, Veenhuis M, Brul S, Klis FM, De Groot PWJ, Müller WH, van Driel KGA, Boekhout T (2011) Cytology, cell walls and septa: a summary of yeast cell biology from a phylogenetic perspective. In: Kurtzman C, Fell JW, Boekhout T (eds) The yeasts: a taxonomic study, I (5th edn): 111-128. Elsevier Science, Burlington. https:// doi.org/10.1016/B978-0-444-52149-1.00008-2

Vermeulen H (1999) Paddestoelen, schimmels en slijmzwammen van Vlaanderen. De Wielewaal, Turnhout

Vert M, Doi I, Helwich K-H, Hess M, Hodge P, Kubisa P, Rinaudo M, Schué F (2012) Terminology for biorelated polymers and applications (IUPAC recommendations 2012). Pure Appl Chem 84:377410. https://doi.org/10.1351/PAC-REC-10-12-04

Wagner I (2019) Cyathicula cyathoidea (Bull.: Mérat) de Thuemen 1874. http://asco-sonneberg.de/pages/gallery/cyathicula-cyathoidea100724-01xs-col9221.php

White WL (1941) A monograph of the genus Rutstroemia (Discomycetes). Lloydia 4:153-240

White WL (1944) Studies in the genus Helotium IV: some miscellaneous species. Farlowia 1:599-617

Wieschollek D, Helleman S, Baral HO, Richter T (2011) Roseodiscus formosus spec. nov. - ein bryophiler Pionier mit falschem Namen. Z Mykol 77:161-174

Yoneda A, Doering TL (2006) A eukaryotic capsular polysaccharide is synthesized intracellularly and secreted via exocytosis. Mol Biol Cell 17:5131-5140. https://doi.org/10.1091/mbc.e06-08-0701

Zhuang WY, Zheng HD, Ren F (2017) Taxonomy of the genus Bisporella (Helotiales) in China with seven new species and four new records. Mycosystema 36:401-420. https://doi.org/10.13346/j. mycosystema. 160193

Publisher's note Springer Nature remains neutral with regard to jurisdictional claims in published maps and institutional affiliations. 